\title{
Review
}

\section{Political realism in apocalyptic times}

\author{
By Alison McQueen \\ Cambridge University Press, Cambridge, 2018, xiii+235 pp., \\ ISBN: 9781107152397
}

Contemporary Political Theory (2019) 18, S45-S48. https://doi.org/10.1057/s41296018-0230-7; published online 4 June 2018

At a time when the study of the theological underpinnings of political thought is gaining ground, Alison McQueen's new book is good news. As McQueen reminds us, political theorists often pass over the fact that half of Hobbes' Leviathan is a treatise on eschatology and ecclesiastical governance, or that Machiavelli concludes the Prince with a prophetic exhortation for the salvation of Italy from the 'barbarians' who periodically invaded it. Even a secularist like Morgenthau could not escape the allure of religious imagery in his most existentialist moments. McQueen's fascinating book is due credit both for bringing these associations to the fore, thus joining the chorus of the 'theological turn' in political theory, and for forensically excavating the complex engagement of some of the doyens of realist thought with the symbolic resources provided by theological ideas and texts.

In this meticulously argued study, McQueen investigates how well the realist credentials of Machiavelli, Hobbes and Morgenthau fare against the challenge presented by the 'apocalyptic imaginary', which she takes to be the dominant cultural reservoir of ideas, symbols and images saturating the Renaissance and early modern Zeitgeist, up to its revamping in the nuclear era. McQueen is aware that examining these three thinkers jointly as part of a 'realist tradition' may expose her to criticisms from Cambridge School historians for 'overzealous doctrinehunting and tradition-building' (p. 17). Yet her interpretive path aims to transcend the opposition between Cambridge School contextualism and the traditional history of ideas. Although she unequivocally assumes that it makes sense to talk about a relatively 'coherent realist tradition' that persists through time, she offers a careful contextual reading of the book's three protagonists. For her, the realist sensibility can be summarised in three key ideas: politics as a tragic conflict between competing, potentially incommensurable, values; a cyclical, anti-teleological understanding of political time; and an appreciation of the contingency that governs political life. Having defined realism as an almost neo-pagan, passive nihilist doctrine (largely following John Gray, Bernard Williams and Raymond Guess), she then juxtaposes it with the apocalyptic imagination. She reconstructs

(c) 2018 Macmillan Publishers Ltd., part of Springer Nature. 1470-8914 Contemporary Political Theory Vol. 18, S1, S45-S48 www.palgrave.com/journals 
the latter as the dualistic worldview announcing the cataclysmic and imminent destruction of the current world in anticipation of a 'new age' of bliss and prosperity. Apocalypticism, in a sense, is a theodicy that ruptures history from a transcendent outside, 'a revelatory moment around which the past is given meaning and a radically new future is announced' (p. 56, emphasis in the original).

In the next three chapters on Machiavelli, Hobbes and Morgenthau, McQueen exemplifies what she takes to be the two main strategies of the realist response to the apocalyptic imaginary: rejection and redirection. Primarily anti-utopian thinkers, the realists are fundamentally suspicious of religious eschatological fervour run amok. Simultaneously, however, they resist the path of cynicism and despair that a complete abandonment of a concern for hope and meaning in the world would entail. McQueen reads the realists as being caught in this perennial dilemma, oscillating between these two options: either taming the destructive effects of the apocalyptic imaginary or recruiting its promising resources for installing what she calls a 'salutary fear' of its destructive potential. Machiavelli exemplifies such an ambivalence in his qualified rejection of the Savonarolan apocalyptic moment. McQueen superbly demonstrates how Machiavelli's political theological project makes him hard to classify. His engagement with theological tropes reveals how his republicanism and tragic realism is a constant struggle to reconcile tragic failure in politics with the necessity of hope. The prophetic tenor of the last chapter of the Prince and the moral realism of his Discourses should be read, McQueen argues, as signs of his failure 'to make an unruly politics intelligible and therefore susceptible to princely mastery' (p. 104). Perhaps unbeknownst to her, the implication here seems to be that realism's failure, far from confirming the impossibility of a world without politics, as she declares, rather lays bare the futility of the politics of mastery or, put differently, politics as the liminal struggle with the inevitability of its own failure.

The chapter on Hobbes is equally captivating although driven by a specific understanding of katechontic eschatology as a conservative device employed to prevent apocalyptic chaos. For McQueen, Hobbes conjures up the horrors of the state of nature and civil war as a secular apocalyptic scenario that seeks to instil fear in the hearts and minds of the Sovereign's subjects. McQueen here reads Hobbes' alternative Christian eschatology that seeks to denounce the fanaticism of false prophets and control religious enthusiasm as aligned with what she interprets as the legitimist eschatologies of Paul and Augustine. She thinks that the two serve the same purpose, the only difference being that Hobbes entrusts the role of the restrainer (katechon) not to the Church as the embodiment of Christ, but rather to the secular state with the Sovereign performing a Christ-like role. It is a vision of reversed redemption that employs apocalyptic terror to secure order and obedience until the Parousia. Hobbes' secular eschatology could indeed be read as fulfilling such a function. However, I would hardly describe such an attitude as Pauline or Augustinian, unless one dilutes the meaning and scope of eschatology-traditional 
as well as in its twentieth-century revival-by obscuring the fact that it has primarily been a theological discourse of hope and indictment/judgement of the powers that be. Whenever the dilemma is between eschatology, either as a quietist subordination to the right authority or as degeneration into apocalyptic revolutionism, then the genuinely political dimension of eschatology is lost. ${ }^{1}$

Apocalypticism with its dualism of a corrupt world vs a redeemed humanity, and its anticipation of a frictionless future brought about by a transcendent act of divine intervention is indeed antipolitical in its orientation and post-political in its expectations. Yet, the eschatological wager is not necessarily between some passively nihilistic tragic sensibility and apocalyptic destruction/transformation, as McQueen seems to think. The consensus among critical biblical scholars is that both Paul and Augustine have a more dynamic eschatology in mind, which stresses equally the sanctification of worldly existence after the resurrection (the already) and the anticipation of this transformative process's completion (the not yet). Such an eschatology is distinctly anti-apocalyptic without simultaneously falling prey to tragic scepticism or resignation. For instance, Jürgen Moltmann's and Johannes Baptist Metz's twentieth-century political theologies are inspired by such an eschatological sensibility that refuses to surrender Christian hope either to tragic scepticism or cataclysmic apocalypticism.

Machiavelli, Hobbes and Morgenthau may not be the best candidates to exemplify such a sensibility. Especially in Morgenthau's case, McQueen is probably right to argue that Morgenthau's theorising 'under an empty sky' leaves him with no choice but to conjure the prospect of nuclear annihilation as a perverse politics of hope through destruction. ${ }^{2}$ Yet, realist political theology is not necessarily exhausted by those options. Paul and Augustine have also been the inspiration behind Christian realism - the elephant in the room in McQueen's book representing a variant of twentieth-century realist thought that actively sought to transcend the tragedy/apocalypse false opposition. There is no space here to elaborate on this point, but the titles of Reinhold Niebuhr's 1937 and 1949 books, Beyond Tragedy and Faith and History, respectively, are telling of this 'third' way I am alluding to here: a treatment of eschatology that not only serves to tame or manipulate apocalyptic exaltation (status quo/katechontic function), but also to keep the hope of salvation alive and God mystically present in history as an indictment to worldly idols, such as the state, the nation, or the people (critical/antikatechontic function). Machiavelli, Hobbes and Morgenthau are not Christian realists, and their humanist secular eschatologies are made up only of fragments of theological tropes. But the realist ambivalence between scepticism and hope may well be a distant echo of such a fragmented eschatological sensibility. One interpretive possibility, then, that McQueen could have considered is that the realist attitude is not necessarily tortuously ambivalent between tragedy and apocalypse; rather, it rejects these two extremes in favour of a politics of qualified hope. Acknowledging this may then better explain why Machiavelli assumes a prophetic

(c) 2018 Macmillan Publishers Ltd., part of Springer Nature. 1470-8914 Contemporary Political Theory Vol. 18, S1, S45-S48 S47 
tone in the last chapter of the Prince or why Hobbes and Morgenthau are suspicious of utopian schemes of progress in politics, without thereby equating their antiutopianism with a renunciation of the irrepressible role hope plays in politics.

\section{Notes}

1 Indeed, recently Agamben (2015) has criticised the Hobbesian katechontic eschatology as a betrayal of true eschatology. Building on the revival of eschatology in the twentieth century (Troeltsch, Metz, Moltmann, von Balthasar), Agamben recruits the critical function of eschatology against the perpetuation of the economic governance of things in modern biopolitics, which he identifies with 'hell'.

2 McQueen's chapter on Morgenthau, while intriguing, relies somewhat uncritically on Nicholas Guilhot's overstated depiction of Morgenthau as a reactionary modernist disciple of Carl Schmitt. Apart from William Scheuerman and Michael Williams, both of whom she cites, McQueen neglects a host of other Morgenthau specialists (e.g. Richard Ned Lebow, Hartmut Behr, Felix Rösch, Muriel Cozette, Vibeke Tjalve, Sean Molloy, Mihaela Neacşu), who emphasise Morgenthau's personal dislike for Schmitt as well as his intellectual disagreements with Schmitt's conservatism. Having contributed to this literature, I would take McQueen's only slightly qualified adoption of Guilhot's minority view with reservations.

\section{Reference}

Agamben, G. (2015). Stasis: Civil war as a political paradigm. Stanford: Stanford University Press.

Vassilios Paipais

School of International Relations, University of St Andrews, St Andrews KY16

9AX, Scotland, UK vp31@st-andrews.ac.uk 